\title{
PENDIDIKAN SUSILA SEBAGAI UPAYA MENCEGAH KENAKALAN REMAJA
}

\author{
Oleh: \\ I Ketut Sudarsana \\ Institut Hindu Dharma Negeri Denpasar \\ iketutsudarsana@ihdn.ac.id
}

\begin{abstract}
Abstrak
Kenakalan remaja terjadi karena kegagalan menjalani proses-proses perkembangan kejiwaan, baik saat remaja maupun masih dalam masa anak-anak. Masa anak-anak dan remaja sesungguhnya dialami dengan begitu singkat, sehingga terkadang antara fisik, psikis, dan emosi tidak berkembang secara bersamaan. Secara psikologis, kenakalan remaja merupakan wujud dari konflikkonflik yang tidak terselesaikan dengan baik pada masa anak-anak maupun remaja para pelakunya. Remaja terkadang mengalami tekanan psikologis dalam masa lalunya yang merupakan akibat dari perlakuan kasar dan tidak menyenangkan dari lingkungannya. Selain itu juga terjadi tekanan psikologis terhadap kondisi lingkungannya, terutama menyangkut ekonomi yang membuatnya merasa rendah diri. Pendidikan susila yang berlangsung di sekolah diharapkan mampu membentuk perilaku spiritual remaja yang sesuai ajaran Agama Hindu, serta menjauhi segala perilaku yang menjurus kepada kenakalan remaja.

Kata Kunci : Pendidikan Susila, Kenakalan Remaja
\end{abstract}

Abstract

Juvenile delinquency occurs because of failure to undergo psychological development processes, both as a teenager and still in childhood. The childhood and teenage years are actually experienced so briefly, so sometimes between physical, psychological, and emotion does not develop simultaneously. Psychologically, juvenile delinquency is a manifestation of unresolved conflicts well in childhood as well as adolescent perpetrators. Teenagers sometimes experience psychological distress in their past which is the result of rough and unpleasant treatment of the environment. In addition, there is also psychological pressure on the condition of the environment, especially regarding the economy that makes him feel inferior. Susila education that takes place in schools is expected to be able to form the spiritual behavior of adolescents according to the teachings of Hinduism, as well as away from any behavior that leads to juvenile delinquency.

Keywords: Susila Education, Juvenile Delinquency

\section{PENDAHULUAN}

Kehidupan para remaja sudah sangat kompleks, dimana banyak diantaranya terlibat pada penyalahgunaan obat terlarang yang disebut psikotropika serta penyebarannya pun telah sam- pai pada wilayah pedesaan yang jauh dari kota. Para remaja sudah terbiasa dengan kehidupan minuman keras yang memabukkan dan terlibat sebagai pemakai narkoba bahkan menjadi pengedar jaringan perdagangan obat terlarang itu. Tentu salah jika mem- 
biarkan situasi yang demikian merosot cendrung mengabaikan nilai-nilai kehidupan yang mulia dan mulai tidak memperhatikan norma-norma moral sehingga terjadi perubahan orientasi perilaku remaja terhadap aktivitas keagamaan Hindu. Kemerosotan moral remaja dan prilaku asusila tentu tidak dibenarkan dalam agama Hindu.

Remaja sering tidak memperhatikan etika sesama teman di sekolah, terhadap guru dan terhadap unsur sekolah lainnya, tidak mematuhi peraturan-peraturan yang terdapat di sekolah. Contoh dari sikap yang tergolong mengabaikan peraturan sekolah adalah sering datang terlambat, tidak menggunakan seragam lengkap sesuai dengan aturan sekolah, sering acuh terhadap guru di sekolah.

Dalam ruang kelas sering keluar masuk tanpa tujuan yang jelas tidak mendapatkan izin dari guru kelas ataupun guru piket yang sedang bertugas, sering berkelahi (tawuran) antar kelas ataupun perkelahian-perkelahian kecil yang menyebabkan proses pembelajaran terganggu. Baik siswa yang melakukan perbuatan di sekolah sendiri tersebut maupun siswa yang lain juga merasa terganggu dengan hal tersebut. Fenomena kenakalan remaja seperti uraian di atas secara konsisten terus meluas, bahkan tidak hanya dikota namun juga terjadi di desa. Kenakalan remaja telah menjadi lingkaran hitam yang terus menyambung dari waktu ke waktu, dari masa ke masa, dari tahun ke tahun dan bahkan dari hari ke hari yang semakin rumit.

Sejalan dengan arus teknologi dan informasi yang semakin berkembang telah memicu modernisasi di segala bidang. Hubungan antar kotakota besar dan daerah semakin lancar, cepat dan mudah. Hal ini menyebabkan kenakalan remaja menjadi masalah yang kompleks dan terjadi di se- luruh daerah Indonesia. Kemajuan teknologi dan informasi yang semakin maju, disamping memudahkan dalam mengetahui berbagai informasi di berbagai media, disisi lain juga membawa suatu dampak negatif yang cukup meluas diberbagai lapisan masyarakat. Cinta dan perilaku seks pranikah merupakan salah satu masalah terbesar dari kaum remaja di mana pun di Indonesia.

Kehamilan pranikah telah banyak menyebabkan remaja melakukan tindakan tidak manusiawi yakni pengguguran kandungan. Kehamilan pranikah juga menyebabkan terputusnya sekolah, perkawinan dini, perceraian, penyakit kelamin, penyalahgunaan obat merupakan akibat buruk petualangan cinta dan seks yang salah di usia remaja. Keinginan mencoba dan rasa ingin tahu yang tidak dibimbing oleh orang dewasa, disertai kurang pertimbangan rasional dan pengetahuan yang cukup telah menjerumuskan remaja pada berbagai bentuk kenakalan.

Secara psikologis, kenakalan remaja merupakan wujud dari konflikkonflik yang tidak terselesaikan dengan baik pada masa anak--anak maupun remaja, sehingga pendidikan susila yang berlangsung di sekolah diharapkan mampu membentuk moral, etika dan spiritual anak didik yang sesuai dengan ajaran Agama Hindu.

Pendidikan di sekolah merupakan suatu proses belajar mengajar yang membiasakan para warga masyarakat sedini mungkin untuk menggali, memahami, menyadari, menguasai, menghayati dan mengamalkan semua nilai yang disepakati, sebagai nilai yang terpuji dan dikehendaki. Penanggulangan berbagai kenakalan remaja tersebut, tentu tidak bisa hanya dibebankan pada sekolah. 
Orang tua harus terlibat secara aktif membimbing dan menjadi tauladan bagi anak-anaknya. Dalam kutipan bait Kitab Nitisastra (Canakya Niti) Bab II, Sloka 10 disebutkan sebagai berikut:

Putras ca vividhaih silair ni yojyah satatam budhaih niti-jnah sila sampanna bhavanti kula pajitah Terjemahan :

Orang bijaksana hendaknya mengajarkan putranya tata susila, pengetahuan NitiSastra dan ilmu pengetahuan suci lainnya, sebab seorang putra yang mahir dalam pengetahuan NitiSastra dan pengetahuan suci lainnya akan menyebabkan keluarga terpuji.

Orang tua berkuasa dalam memerintah keluarga dan bertanggung jawab atas perlindungan terhadap fisik dan perkembangan jiwa anak-anaknya, serta mempersiapkan untuk menjadi orang dewasa tidak ada unsur kesatuan lain diluar keluarga yang dapat menjalankan tugas ini. Orang tua berhasil atau gagal mempersiapkan anakanaknya dengan menyelenggarakan pendidikan informal, mengembangkan citra diri yang utama, mempelajari tanggung jawab dan nilai-nilai hanya dengan menjadi bagian dari sistem keluarga (Sudharta, 1994 : 15).

Perubahan orientasi para remaja sudah terjadi di berbagai daerah karena hampir setiap hari terdapat pemberitaan yang memberitakan masalah kehidupan remaja baik yang berda di kota-kota besar, di kota-kota kabupaten bahkan sampai pedesaan yang terpencil. Orientasi yang keliru akan membawa sikap tidak cocok dengan pengalaman dan dinamika hidup yang semestinya dilakukan.

Kesalahan

orientasi sesungguhnya dapat dicegah agar tidak mengalami kesalahan yang lebih patal, membahayakan, mengacaukan, bahkan menjadi insan yang berfikiran fanatisme sempit pada akhirnya akan merugikan dirinya dan masyarakat yang lebih luas. Sesungguhnya perubahan orientasi tidak semua memiliki tendensi yang negatip, dewasa ini di era globalisasi dengan informasi mendunia perubahan orientasi terjadi akibat dari adanya pergeseran kepentingan. Dua atau tiga puluh tahun yang silam kondisinya jauh berbeda dengan sekarang.

Dahulu masih sedikit orang yang bisa memiliki handphone (HP), begitu menyaksikan orang berkomunikasi menggunakan HP terlihat sebagai sosok memiliki status yang tinggi. Puluhan tahun yang silam mobil dan sepeda motor tidak begitu padat seperti sekarang dampak terhadap kehidupan dari kemajuan teknologi dan hasil dari industri tersebut semakin terjangkau maka hubungan dengan dunia luar semakin tidak terbatas baik waktu maupun jarak.

Itulah perubahan orientasi terjadi dalam tatanan kehidupan para remaja. Jika ingin nilai positip bagi remaja sesungguhnya tergantung bagaimana cara memandang dan mengimplementasikan tata krama dalam kehidupan remaja.

\section{PEMBAHASAN}

2.1 Perubahan Perilaku Remaja Dalam Tinjauan Pendidikan Susila

Menurut Willis (2005:19) menyatakan bahwa remaja bukan kanak-kanak lagi, akan tetapi belum mampu memegang tanggung jawab seperti orang dewasa. Para remaja mengalami proses perubahan perilaku terhadap aktivitas agama Hindu. Aktivitas agama Hindu di sekolah sesungguhnya bukan saja kegiatan ritual keagamaan tetapi juga perilaku 
remaja itu sendiri sebagai seorang pelajar. Menurut Panuju (1999 : 29), para remaja membutuhkan agama, manusia dari sejak lahir sudah membutuhkan agama karena dalam hal ini agama yang berkaitan dengan kehidupan ialah tindakan yang diyakini oleh pikiran, diresapkan oleh perasaan dan dilaksanakan dalam tindakan, perbuatan, perkataan dan sikap.

Remaja tidak akan memiliki perbedaan yang jauh dengan remaja di sekolah yang lain. Sebagaimana disebutkan oleh Willis (2005: 19) remaja memiliki tiga ciri yaitu : 1) ciri primer yaitu matangnya organ seksual yang pada remaja wanita ditandai dengan adanya menstruasi.

Pada anak laki-laki ditandai dengan adanya produk cairan sperma pertama (noctural seminal emission), 2) ciri sekunder yaitu adanya perubahan bentuk tubuh pada kedua jenis kelamin itu. Anak wanita mulai tumbuh buah dada (susu), pinggulnya sudah mulai membesar, paha juga mengalami pembesaran karena tumpukan zat lemak. Pada anak laki-laki terjadi perubahan otot, bahu melebar, suara mulai berubah, tumbuh bulu-bulu pada alat kelamin dan ketiak, serta kumis pada bibir, 3) ciri tertier adalah ciriciri perubahan tingkah laku yang tampak seperti peubahan minat, antara lain berkurangnya minat belajar, timbul minat pada jenis kelamin lainnya dan juga minat terhadap pekerjaan menurun.

Sebagaimana yang disebutkan oleh Daradjat (Willis, 2005: 22) menyatakan bahwa remaja sebagai usia transisi dimana seorang individu, telah meninggalkan usia kanak-kanak yang lemah dan penuh ketergantungan. Namun seorang yang baru menginjak remaja belum mampu ke usia yang kuat dan penuh tanggung jawab, baik terhadap dirinya maupun terhadap masyarakat.

Dalam ajaran susila, pengendalian diri merupakan cerminan keimanan dan kehidupan beragama yang berhubungan dengan diri sendiri, sesama manusia, baik dalam lingkungan keluarga, masyarakat, bangsa dan negara bahkan dalam hubungan internasional antar bangsa-bangsa. Dengan pengendalian diri yang bersumber pada keimanan yang merupakan inti sari ajaran agama, sebagai keyakinan hidup serta berbagai pengalaman sangat berguna untuk mewujudkan kesejahteraan, keharmonisan dan kebahagiaan hidup.

Dengan ajaran etika dan pengendalian diri yang mantap, seperti seseorang yang tertib berlalu lintas, dia akan berhasil dan selamat mencapai tujuan. Demikian pula seseorang yang memiliki keimanan yang kuat dan mampu mengendalikan diri, akan selamat di dunia ini dan di akhirat, untuk itu agama hendaknya benar-benar menjadi landasan dan pegangan setiap orang. Peranan pendidikan susila di sini sangat membantu dalam pencegahan kenakalam remaja dalam penyalahgunaan obat terlarang.

Agama merupakan jalan lengkap dengan papan-papan petunjuk yang menuntun umat manusia ke arah yang benar. Tanpa tuntunan agama, mungkin manusia akan sesat dan tidak tahu arah, sehingga akhirnya tujuan hidup tidak tercapai. Sebagaimana dikemukakan bahwa agama itu diibaratkan sebagai sebuah perahu, sedangkan jiwa atau atma adalah nahkodanya, layarnya adalah perasaan, kemudinya adalah pikiran, anginnya adalah pulau harapan atau sorga (Putra, 1987:16). Tata susila artinya peraturan--peraturan tentang tingkah laku yang baik.

Peraturan ini timbul karena orang hidup bersama-sama dengan 
orang lain, makhluk lain dan alam semesta. Di dalam hidup bersama dengan masyarakat setiap orang diharuskan bertingkah laku sedemikian rupa yang membawa kebahagiaan terhadap dirinya sendiri dan terhadap masyarakat. Barang siapa yang melanggar peraturan tingkah laku ini akan membawa kerugian kepada dirinya sendiri, kapada masyarahat.

Kerugian itu misalnya kesusahan hati, tekanan bathin, rasa malu, rasa berdosa, kerusuhan-kerusuhan di dalam masyarakat dan lain-lain. Kalau perbuatannya baik maka baik pula akibatnya dan bila perbuatannya buruk maka buruk pula akibatnya. Kalau orang berani mengiris kulitnya, alam akan memberikan hukumanya yaitu orang itu akan merasa sakit dan terluka. Tidak ada yang luput dari hukum alam dengan menyadari hukum alam itu orang akan mengatur dirinya dalam berbuat suatu sesuai dengan hukum alam itu agar selamatlah hidupnya di dunia ini. Budi pekerti yang luhur akan tercipta keharmonisan dan keseimbangan.

Hubungan yang harmonis tidak hanya dilakukan hanya antar manusia saja tetapi harus juga dengan makhlukmakhluk lain dan dengan alam sekitar. Bila manusia telah seimbang kembalilah tentram hidup ini. Sulit dibayangkan akan adanya hidup yang bahagia dan tentram tanpa disadari atas budi pekerti. Dimana orang-orang berbudi rendah berkumpul, maka disana akan di jumpai kehidupan yang serba kacau, sehingga kecemasan dan kejahatan selalu mengancamnya.

Budi pekerti yang luhur tidak hanya mengantar orang kepada kebahagiaan hidup di dunia ini, tetapi juga kepada kebahagiaan hidup di akhirat. Di dalam Sarasamuscaya sloka 384 dijelaskan sebagai berikut :

Apan sang sadhu ngaranira, yadyapin konen sira ring ulah salah, tan pangidep juga sira, tan rengerengan, kunang ikang wwang dusta, yadyapin uhutana towi ring ulah salah, inulaha kenya juga ya

Terjemahannya :

Orang yang disebut sadhu (utama budi) biarpun diperintahkan untuk berbuat dosa, sekali -kali beliau tidak akan menurut dan tidak akan mentaati perintah itu, akan tetapi orang yang berhati jahat, meski ia dilarang agar tidak melakukan perbuatan jahat, namun dilakukan saja olehnya (Kadjeng, 2005:256).

Sloka tersebut menjelaskan orang yang utama budinya biarpun diperintahkan untuk berbuat dosa, sekali-kali beliau tidak akan menurut, dan tidak akan mentaati perintah itu, akan tetapi orang yang berhati jahat, mesti ia dilarang agar tidak melakukan perbuatan jahat namun dilakukan olehnya. Meningkatkan pengetahuan Wiweka, daya selektif dalam memilih dan menerima pengaruh-pengaruh luar perlu ditingkatkan melalui ajaran wiweka, agar mampu membedakan yang baik maupun yang tidak baik.

Sejak kecil remaja sudah mempunyai kemampuan untuk membeda-bedakan antara tingkah laku, etika yang baik dan yang buruk, salah dan benar. Kesanggupan remaja itu perlu diperkuat oleh pendidikan orang tua dan pengaruh lingkungan tempat remaja berada, sehingga semakin sadar bahwa tingkah laku yang benarlah yang harus selalu dilaksanakan. Makin lanjut umur makin luas pengetahuan manusia maka makin tinggi kesadarannya akan apa yang disebut salah dan benar itu. Kemampuan untuk menimbang dan membeda-bedakan antara salah dan benar, baik dan buruk 
itulah disebut wiweka. Kitab Sarasamuscaya 315 menguraikan sebagai berikut :

Matangnyan haywa tan pawiweka, awakta ta pwa umangênangêna

ulahnyāwakta sārisāri, linganta, salah kariki ulahta, yukti karika, pada lawan pasu kariki mangke, pada lawan sang pandita kunang, deniki prawrttinta, mangkana linganta sārisārin yatnatutura ri prawrttinta.

Terjemahannya :

Oleh karena itu janganlah hendaknya tanpa pertimbangan atau penyelidikan, hendaklah anda memikirkan perbuatan diri anda sehari-hari, pikir anda; "apakah salah perbuatan ini atau benarkah; sama dengan hewankah atau sama dengan panditakah tingkah lakaku" demikian hendaknya pikiran anda dari hari ke hari dan anda senantiasa menasehati diri mengenal perbuatan anda itu (Kajeng, 2005:237238).

Kutipan di atas menekankan betapa pentingnya remaja meningkatkan wiweka yaitu merenungkan dengan cermat sebelum sesuatu perbuatan itu dilaksanakan agar betulbetul tidak menyimpang dari kebenaran. Perbuatan tanpa pertimbangan yang matang cenderung terjerumus ke dalam perbuatan yang tidak baik dan benar yang pada akhirnya akan membawa kesengsaraan.

Dalam segala hal remaja patut berdasarkan tingkah laku atau perbuatannya pada wiweka yaitu pertimbangan-pertimbangan. Tentu saja pertimbangan--pertimbangan tersebut tidak boleh berdasarkan atas pertim-

bangan dan ukuran pribadi belaka sebab pertimbangan dan ukuranukuran pribadi itu tidak selamanya dapat dipakai pedoman yang baik. Remaja harus berpedoman pada ukuran-ukuran kebenaran umum.

\subsection{Pendidikan Susila dalam Mencegah Kenakalan Remaja}

Susila merupakan bentuk pengendalian diri dalam pergaulan hidup (Sura, 1985:38). Dalam hubungannya dengan susila atau perbuatan serta tingkah laku, makanya tingkah laku orang dapat dinilai pada tiga tingkatan, yaitu: 1) Semasih dalam bentuk anganangan, atau niat; 2) Sesudah berbentuk pekerti atau perbuatan nyata; 3) Akibat atau hasil yang diperoleh oleh pakerti ini, baik ataupun buruk adalah kekal. Ibarat landasan bangunan, dimana suatu bangunan harus didirikan. Jika landasan tidak kuat, maka sudah tentu bangunannya akan roboh demikian pula dengan tatasusila, bila tidak dibangun atas dasar agama yang kokoh dan kekal, makanya tatasusila itu tidak mendalam dan tidak meresap dalam diri pribadi manusia (Mantra, 1993:7).

Jika tatasusila mendasarkan ajarannya hanya kepada keesaan Sang Hyang Widhi Wasa saja, yang menyadari dasar semua makhluk, ini berarti tiap perbuatn baik atau tidak baik dilakukan oleh seseorang pada orang lain berarti juga perbuatan baik atau tidak baik pada diri sendiri. Maju mundurnya suatu bangsa sangat ditentukan oleh pendidikan yang dimiliki oleh masingmasing warganya.

Standar pendidikan yang begitu rendah tidak akan menunjang kelancaran usaha untuk maju menuju kemajuan serta suksesnya pembangunan di jaman modem dewasa ini, seseorang berlomba-lomba belajar ilmu pengetahuan untuk mengisi ke- 
hidupannya. Dengan memahami ilmu pengetahuan seseorang akan lebih mudah dalam hidupnya. Dewasa ini tidak ada pekerjaan dapat dilakukan tanpa memiliki kepandaian atau ketrampilan lebih--lebih dalam usaha meningkatkan kesejahteraan hidup.

Pendidikan itu diperoleh dengan berbagai cara, baik secara formal, maupun informal, pendidikan formal didapatkan melalui sekolahsekolah, lembaga--lembaga pendidikan lainnya, sedangkan pendidikan informal bisa didapatkan melalui pergaulan-pergaulan baik dari keluarga, masyarakat dan lingkungan dimana di berada. Perkembangan kepribadian anak memang ditentukan oleh Tri Pusat pendidikan tersebut.

Kiranya sependapat melalui Tri Pusat Pendidikan (keluarga, sekolah, masyarakat) remaja dapat melakukan secara bersama-sama dan bahu membahu dalam menangkal kenakalan remaja dengan penuh kearifan demi tercapainya tujuan mulia dengan resiko yang sekecil-kecilnya, baik oleh para pendidik, orang tua, pemuka agama, penegak hukum, dokter, psikolog, dan pejabat pemerintah. Secara preventif maupun secara kuratif atau refresif.

Proses pendidikan susila di rumah tangga patut dilaksanakan secara bijaksana oleh orang tua, menyesuaikan dengan perkembangan umur si anak. Seperti dijelaskan dalam kitab Niti Sastra sebagai berikut :

Tingkahning suita sasaneka kadi raja tenaya

Ri sedeng limang tahun,

Sapta ng warsa wara hulun sapuluhing

Tahun ika wuruken ring aksara,

Yapwan sodasawarsa tulya mitra

Tinaha-taha denta midana,
Yan wus putra suputra tinghalana solahika

Wurupan ing nayengita

Terjemahannya :

Anak yang sedang berumur lima tahun hendaknya diberlakukan seperti anak raja

Jika sudah berumur tujuh tahun, dilatih supaya suka menurut

Jika sudah sepuluh tahun diberi pelajaran membaca,

Jika sudah enam belas tahun diperlakukan sebagai sahabat, kalau kita menunjukkan kesalahannya harus dengan hati-hati sekali Jika ia sendiri sudah beranak, diamat-amati saja tingkahnya, kalau hendak memberi pelajaran kepadanya cukup, dengan gerak dan isyarat saja.

(Nitisastra, Sargah IB bait 20)

Kesalahan pendidikan susila di rumah tangga dengan memanjakan anak justru akan berakibat yang tidak baik, bukan saja bagi diri si anak juga berpengaruh negatif terhadap keluarga. Dijelaskan dalam Nitisastra sebagai berikut :

Haywanglalana putra sang sujana dosa temahika wimarga tan wurung

Terjemahannya :

Jangan memanjakan anak, anak yang dimanjakan akan menjadi jahat dan pasti akan menyimpang dari jalan yang benar (Nitisastra, sargah IV, bait 21).

Orang tua sejauh mungkin sangat dianjurkan untuk mengamati pergaulan putra-putrinya agar jangan terjerumus dalam pengaruh pergaulan tidak baik apalagi sampai terlibat dalam kenakalan remaja. Orang Tua merupakan pengisi hati nurani yang pertama bagi anak. Maka wajarlah orang tua memiliki tanggung jawab 
untuk memelihara, membimbing dan mendidik anak-anaknya sehingga anak bisa mencapai kehidupan yang lebih baik dan memiliki mental spiritual yang kokoh dan menjadi anak yang suputra.

Berkaitan dengan ini yang dimaksud orang tua adalah ayah, ibu kandung yang merupakan orang pertama pada anak sejak lahir. Orang tua merupakan sebagai pengisi hati nurani yang pertama pada anak, maka wajarlah orang tua merasa memiliki tanggung jawab untuk memelihara, membimbing, mengarahkan dan mendidik anak-anaknya sehingga anak tersebut bisa mencapai kehidupan yang lebih baik dan memiliki mental spiritual yang kokoh serta menjadi anak yang suputra.

Orang tua mempunyai pengaruh yang sangat besar terhadap perkembangan fisik anak maupun perkembangan jiwa (mental). Orang tua merupakan sumber pemuas kebutuhan bagi si anak dan prilaku orang tua penting dalam menentukan apakah seorang anak akan mengalami kesulitan kepribadian atau tidak dalam hidupnya kelak. Dalam Candakya Nitisastra II .11 akan disebutkan sebagai berikut.

\section{Mata sastrupita hairi \\ Yena balo napatitah \\ Na sobate seba madhya \\ Harusa madhya baho yatha \\ Terjemahan.}

Seorang bapak dan ibu yang tidak memberikan pelajaran (pesucian) kepada anaknya mereka berdua adalah musuh dari anak tersebut. Anak tersebut tidak akan ada artinya di masyarakat, bagaikan seekor bangau di tengah-tengah kumpulan burung angsa. (Krishna, 2008:13)

Orang tua adalah orang yang memiliki tanggung jawab terhadap pembinaan, bimbingan, pengembangan serta sebagai pengarah potensi yang dimiliki anak agar remaja dapat berfungsi dan berperan sebagaimana hakekat kejadiannya. Orang tua (ayah dan ibu adalah pendidik kodrati dan remaja diberikan anugrah oleh Tuhan pencipta naluri orang tua karena naluri itu timbul dari rasa kasih sayang kepada anak-anaknya).

Sehingga secara moral keduanya merasa bertanggung jawab untuk memelihara, mengawasi dan melindungi serta membimbing keturunannya (Jalaluddin, 2001:14) Berdasarkan kutipan di atas dijelaskan bahwa orang tua memberikan tanggung jawab terhadap perkembangan anak-anaknya baik perkembangan jasmani maupun perkembangan rohani. Selain itu orang tua mempunyai peran yang sangat besar dalam membimbing, membina dan mendidik serta mengarahkan perkembangan anak-anaknya.

Orang tua adalah merupakan faktor sentral dalam keluarga bagaimana orang tua memperlakukan anak akan berdampak pada pembentukan kepribadian anak. Setiap orang tua memiliki kepemimpinannya tersendiri terhadap anaknya sesuai dengan tipe kepribadian yang dimiliki. Sikap orang tua dapat berbeda dalam menghadapi anak antara yang satu dengan yang lain.

Ada orang tua memperhatikan perkembangan anak secara baik dengan perlakuan menerima secara demokratis adapula orang tua yang menimbulkan komflik dan prustasi pada anak seperti menolak, menguasai, ataupun otoriter. Dan ada pula orang tua yang memberikan kebebasan pada anaknya untuk menentukan segalagalanya (Yadnyawati, 2003 : 36-37) Materi ajaran agama Hindu adalah 
bersumber pada Weda. Apa yang dicantumkan sesuai dengan kutipan sloka dari Sarasamuscaya 40 berbunyi sebagai berikut :

Kunang kangetakena sasing kajar de sang hyang Cruti dharma ngaranika, sekajar de sang hyang smrti kuneng dharma ta ngaranika, cistacara kunang, acaranikasang cista, dharma ta ngaranika, cista ngaran sang hyang satyawadi, sang apta, sang patirthan, sang panadahan upadeca sang ksepa ika katiga, dharma angaranira.

Terjemahanya:

Maka yang patut diingat adalah segala apa yang diajarkan oleh Sruti, disebut dharma, semua yang diajarkan smrti, pun dharma pula namanya; demikian pula tingkah laku sang cista, disebut juga dharma, cista artinya orang yang berkata jujur yang setia pada katakatanya, orang yang dapat dipercaya, orang yang menjadi tempat pesucian diri, orang yang memberikan ajaran-ajaran atau nasihat-nasihat; singkatnya, ketiga-tiganya itu disebut dharma. (Kajeng,dkk, $2005: 33$ ).

Berdasarkan kutipan sloka di atas maka dapatlah dilihat materi pokok dari ajaran agama Hindu, sehingga dapatlah dikatakan bahwa pendidikan susila merupakan suatu upaya membina pertumbuhan dan perkembangan jiwa generasi muda dalam membantu memecahkan masalah-masalah sosial yang di hadapi. Dijelaskan juga dalam Sarasamuscaya sloka 300, bagaimana pengaruh pergaulan antara satu orang ke orang lain saling mempengaruhi. Adapun bunyi slokanya sebagai berikut :
Nyang selangakena, ikang sang-sarga, agelis juganularalan guna ya, irikang lot masang sarga lawan maguna, wyaktinya, nahan yamboning sekar, an tular mara ring dodot wwai, lenga, lemah, makanimitta pasang sarganya lawan ikang kembang.

Terjemahannya :

Inilah tentang pergaulan, lekas benar pergaulan itu memindahkan sifat yang baik kepada orang yang selalu bergaul dengan orang yang bersifat utama, buktinya baunya bunga beralih kepada kain, air, minyak dan tanah. disebabkan persentuhannya dengan bunga itu (Kajeng, dkk, 2005 : 227).

Jadi dari uraian diatas dan pendapat tentang pendidikan susila, maka dapat disimpulkam bahwa, dalam mencegah kenakalan remaja yakni, dalam hal ini orang tua, sekolah dan masyarakat berperan penting dalam memberikan bimbingan moral (susila) terhadap anak sehingga tidak terjadi penyimpangan prikaku terhadap anak khususnya remaja. Pendidikan disekolah merupakan pendidikan yang bersifat formal dan resmi.

Disini cipta, rasa, karsa, karya dan kepribadian anak yang sudah didasari didalam pendidikan keluarga., secara resmi dikembangkan dengan menggunakan rencana pembelajaran yang ditetapkan oleh pemerintah. Pendidikan ini dilaksanakan oleh guru (Citrobroto, 1986 : 7). Pendidikan di masyarakat merupakan pendidikan non formal.

Anak dapat memilih sendiri macam-macam pendidkan yang dikehendaki misalnya kepanduan, olah raga, kesenian, menggambar dan beberapa ketrampilan lainnya. Pendidkan ini dilaksanan oleh pemimpin 
masyarakat seperti pendeta, alim ulama, pastor, pemimpin kepanduan dan beberapa pelaksana pendidikan non formal lainnya. (Citrobroto, 1986:7).

Tugas dan tanggung jawab orang tua, guru dan pemimpin masyarakat utamanya ialah menegakan disiplin, baik disiplin anak dirumah, disekolah, dan dimasyarakat. Bila disiplin telah tertanam dan tumbuh mekar dengan baik, maka sesungguhnya sebagian tugas dalam pencapaian tujuan pendidikan sudah dapat di realisasikan. (Titib, 2003:39).

Dari uraian tersebut,
Keterbukaan pengetahuan tentang bahaya dari seks bebas sejak dini sangat berpengaruh pada prilaku baik di masyarakat dan memupuk kesadaran akan hal-hal yang kearah positif. Dari hal itu dapat dipahami tentang adanya kecenderungan dari kenakalan remaja adalah adanya faktor lain yang turut mempengaruhi seperti :

a. Keadaan ekonomi orang tua

b. Lingkungan keluarga

c. Lingkungan sekolah

\section{d. Lingkungan Masyarakat}

Sesuai dengan ajaran Agama hindu yaitu Slokantara dan Nitisastra bahwa didalam mendidik ank-anak harus disesuikan dengan tingkat Usia dan sewaktu-waktu orang tua harus dapat bertindak sesuai dengan kondisi yang ada, yaitu orang tua harus bersikap demokratis, otoriter dan sewaktuwaktu memberikan kebebasan namun secara diam-diam harus diawasi agar tindakan anak-anak tidak menyimpang ke hal-hal yang bersifat negatif yang dapat menghambat proses pendidikan remaja di sekolah sehingga dapat menimbulkan perilaku-perilaku yang merugikan individu, dan orang lain.

\section{Kesimpulan}

Salah satu yang bisa dilakukan untuk mengatasi kenakalan remaja adalah melalui pendidikan dalam keluarga, mengembangkan potensi remaja, memandirikan remaja, memberikan kemampuan untuk beradaptasi dan perilaku yang diperlukan remaja dalam mengatasi tantangan dan kebutuhan hidup sehari-hari selain itu melalui pendekatan dan komunikasi yang baik antara orang tua dan anak serta melalui berbagai penataan suasana lingkungan yang tepat dimana ajaran agama sebagai dasarnya bagi pendidikan moral remaja.

Sedangkan upaya dari pihak sekolah yaitu : Melalui upaya preventif dengan melakukan pengarahan atau sosialisasi tentang tata tertib siswa sesering mungkin, baik dalam kelas, saat upacara bendera, maupun dalam kesempatan-kesempatan lainnya. Melakukan pembinaan awal berupa: (1) Teguran langsung peringatan lisan kepada siswa bersangkutan. (2) Mengadakan pengecekan dan pencatatan dalam buku harian, (3) Melakukan peringatan tertulis kepada siswa bersangkutan ditujukan kepada orang tua atau wali, Bila masalahnya agak berat maka dilakukan skorsing namun Jika kasusnya sangat berat maka siswa bersangkutan secara hormat dikeluarkan dari sekolah. Pendekatan pendidikan susila untuk menghindari terjadinya kenakalan remaja di sekolah dapat dilaksanakan melalui kurikulum pendidikan sekolah baik secara terpadu dengan mata pelajaran lainnya, maupun secara khusus, baik intra maupun ekstra kurikuler.

Maka dari itu para guru yang bersangkutan perlu mendapat pelatihan khusus : pengelolaan waktu luang dan kegiatan alternatif dengan kegiatan-kegiatan penyaluran hobi, olah raga, kesenian, kegiatan rekreasi bersama atau lainnya. Penanggulangan masalah kenakalan remaja ini perlu 
ditekankan bahwa segala usaha harus ditujukan ke arah tercapainya kepribadian yang mantap, serasi dan dewasa. Remaja diharapkan akan menjadi orang dewasa yang berpribadi kuat, sehat badani dan rohani, teguh dalam kepercayaan dan iman sebagai anggota masyarakat, bangsa dan tanah air.

\section{Daftar Pustaka}

Kadjeng, I N. (2000), Sarasamuccaya, Surabaya: Paramitha

Mantra, I. B. (1993). Tata Susila Hindu Dharma, Denpasar : Proyek Penyuluhan dan Penerbitan Buku Agama.

Panuju, P. (1999). Psikologi Remaja. Yogyakarta. PT. Tiara Wacana.

Sugiharta, I. P. S. O., \& Sudarsana, I. K. (2017). Hypnotic Learning Characteristics On Sisya Brahmakunta Community In Denpasar. Vidyottama Sanatana: International Journal of Hindu Science and Religious Studies, 1(2), 132-145.

Suparna, P. (2001). Teori Perkembangan Kognitif Jean Piaget. Yogyakarta: Kanisius.

Soekanto, S. (1986). Sosiologi Suatu Pengantar. Jakarta : CV. Rajawali.

Sudarsana, I. K. (2018). PEMBERDAYAAN USAHA KESEJAHTERAAN SOSIAL BERBASIS PENDIDIKAN AGAMA HINDU BAGI ANAK PANTI ASUHAN. JCES| FKIP UMMat, 1(1), 4151.

Sudartha, T. R. (2003). Slokantara, Untaian Ajaran Etika, Teks, Terjemahan dan Ulasan. Surabaya : Paramita.

Sudharta, T. R. (1997). Slokantara, Untaian Ajaran Etika, Teks, Terjemahan dan Ulasan,
Denpasar, Upada Sastra.

Sura, I G. (1985). Pengendalian Diri dan Etika Dalam Ajaran Agama Hindu, Jakarta, Hanoman Sakti.

Titib, I M. (2003). Teologi dan Simbol-simbol dalam Agama Hindu. Denpasar : Paramitha

Titib, I M. (2003). Menunbuh Kembangkan Pendidikan Budhi Pekerti pada Anak (Perspektif Agama Hindu). Bandung : Ganeca Exact.

Wilis, S. (1981). Problem remaja dan pemecahanya. Badung : Angkasa.

Wisarja, I. K., \& Sudarsana, I. K. (2017). REFLEKSI KRITIS IDEOLOGI PENDIDIKAN KONSERVATISME DAN LIBRALISME MENUJU PARADIGMA BARU PENDIDIKAN. Journal of Education Research and Evaluation, 1(4), 283-291. 